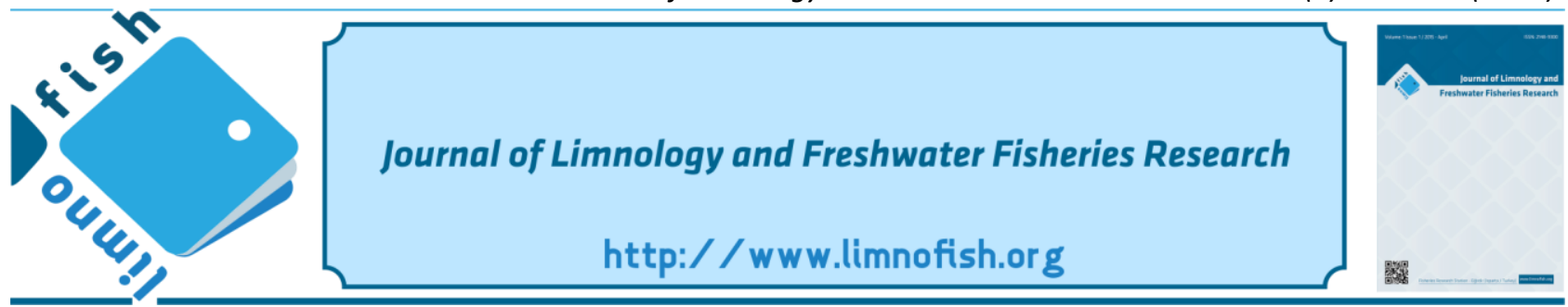

\title{
A Preliminary Study on Reproduction and Development of Bushymouth Catfish (Ancistrus dolichopterus) in Aquarium Conditions
}

\author{
Mustafa DENIZ ${ }^{* *}$ (D), T. Tansel TANRIKUL ${ }^{2}$ (D), Onur KARADAL ${ }^{3}$ (D), Ezgi DİNÇTÜRK ${ }^{2}$ \\ F. Rabia KARADUMAN ${ }^{1}$ (D) \\ ${ }^{1}$ Department of Aquaculture, Graduate School of Natural and Applied Sciences, İzmir Kâtip Çelebi University, 35620, Çiğli, \\ İzmir, Turkey \\ ${ }^{2}$ Department of Fish Diseases, Faculty of Fisheries, İzmir Kâtip Çelebi University, 35620, Çiğli, İzmir, Turkey \\ ${ }^{3}$ Department of Aquaculture, Faculty of Fisheries, İzmir Kâtip Çelebi University, 35620, Çiğli, İzmir, Turkey
}

\section{A B STR ACT}

Dwarf suckermouth catfish are preferred especially for small aquariums. They are usually referred to as tank cleaners and commonly traded in the ornamental fish sector. Since these fish are nocturnal, it is difficult to observe their reproductive behavior and larval development. This study was carried out to determine the reproductive variables of bushymouth catfish (Ancistrus dolichopterus) under aquarium conditions. Three broodstocks bushymouth catfish with an average initial weight and a total length of $10.5 \pm 0.3 \mathrm{~g}$ and $9.5 \pm 0.2 \mathrm{~cm}$ were stocked in three 240-L aquariums with the ratio of 1:2 (male: female). The observations were made in triplicate tanks for six months. Females laid an average of $39.78 \pm 0.41$ eggs and fertilization and hatching rates were $75.05 \%$ and $62.94 \%$, respectively. It was found that the transition time from egg to apparently larval stage was $105.28 \mathrm{~h}$, and bushymouth catfish showed an indistinguishable development from the hatching to juvenile stage without a real larval transition stage. The results of the study provide basic information on the reproductive performance and early development of bushymouth catfish.

Keywords: Ornamental fish, suckermouth catfish, Ancistrus dolichopterus, seed production, larvae

\section{ARTICLE INFO}

\section{RESEARCH ARTICLE}

Received : 28.02.2020

Revised :05.06.2020

Accepted :09.06.2020

Published : :29.12.2020

DOI:10.17216/LimnoFish.695413

\section{* CORRESPONDING AUTHOR}

mustafaa.denizz@gmail.com

Phone : +902323293535

Çalı Ağız Cüce Vatozun (Ancistrus dolichopterus) Akvaryum Koşullarında Üremesi ve Gelişimi Üzerine Bir Ön Çalışma

Öz: Vatozların cüce türleri özellikle küçük akvaryumlar için tercih edilirler. Genellikle tank temizleyiciler olarak adlandırılırlar ve süs balıkları sektöründe sıklıkla ticaretleri yapılır. Bu balıklar gececildir ve üreme performansları ve larval gelişimlerini gözlemek zordur. Bu çalışmada, çalı ağız cüce vatozun (Ancistrus dolichopterus) akvaryum koşullarında üretimi üzerine bir deneme

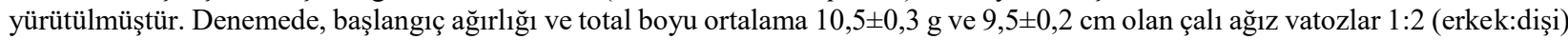
oranı ile $240 \mathrm{~L}$ akvaryumlarda stoklanmıştır. Çalıșma, altı ay boyunca üç tekrarlı olarak gerçekleştirilmiștir. Dișiler ortalama $39,78 \pm 0,41$ adet yumurta bırakmış, döllenme ve yumurtadan çıkış oranları sırasıyla \% 75,05 ve \%62,94 olarak kaydedilmiştir. Yumurtadan larvaya geçiş süresinin 105,28 saat sürdüğü ve çalı ağız vatozun yumurta ve yavru evreleri arasında ayırt edilemez bir gelişme gösterdiği ve gerçek bir larval geçiş evresine sahip olmadıkları bulunmuştur. Çalışmanın sonuçları gelişimsel özellikleri gözlemlenmesi zor olan bu süs balığı türünün gelişimi hakkında temel bilgiler sağlamıştır.

Anahtar kelimeler: Süs balığı, vatoz, Ancistrus dolichopterus, yumurta üretimi, larva

\section{How to Cite}

Deniz M, Tanrikul TT, Karadal O, Dinçtürk E, Karaduman FR. 2020. A Preliminary Study on Reproduction and Development of Bushymouth Catfish (Ancistrus dolichopterus) in Aquarium Conditions. LimnoFish. 6(3): 231-237. doi: 10.17216/LimnoFish.695413

\section{Introduction}

The aquarium is a popular hobby, practiced by aquarists or aquarium enthusiasts, and created a vast industry all over the world. American Pet Products Association reported that $11.5 \%$ of the pet owners in the US have a freshwater aquarium and $1.6 \%$ have a marine aquarium in their homes (APPA 2020). The growth of this sector continues with an annual rate of above 10\% (Bassleer 2015; Dey 2016). In 2017, the total of import and export values of ornamental fish 
trade reached 628,000 $\$($ FAO 2017) and the estimated value of the aquarium sector attained approximately 15-30 billion $\$$ with the side materials, including technical equipment, decorations, ornamental fish food, medicines, additives, chemicals, and others (Penning et al. 2009; Dey 2016). However, as in every sector, a rapid consumption policy in the aquarium sector is one of the biggest problems, which may stop or even reverse this growth. Therefore, encouraging the fish (or other species, such as invertebrates, plants, etc.) production at every stage of consumption will ensure the continuity of the growth in the sector.

Up to $90 \%$ of the freshwater fish in the aquarium industry is supplied by aquaculture (Oliver 2001). Aquarium fish farming is carried out in glass aquariums as well as in more advanced recirculating aquaculture systems (RAS) in modern hatcheries and production facilities. However, it is very important to integrate the production experiences, culture practices, determination of the specific requirements of the species as well as technological developments for the production of aquarium fish whose number exceeds 7000 (Marranzino 2018). In Turkey, the aquarium trade turned into a professional sector after the 1980s. Different species of ornamental fish have been imported since then (Türkmen and Alpbaz 2001). However, diversity and number of fish species in the market continue to increase.

Cichlids, livebearers, labyrinths, cyprinids, catfish, and tetras are important groups of aquarium fish (Hill and Yanong 2010). Among these groups, catfish species are called "tank cleaners" because they take on an important mission like cleaning the aquarium. Especially in small aquariums, dwarf species are more preferred. The bushymouth catfish (Ancistrus dolichopterus) is one of the popular of this group (exporter code L183) and commercially important in the trade (Evers and Siedel 2005; Reis and Lima 2009). This species is originated from the Amazon Basin and the Rio Negro River, Trombetas River, Tefé River, Madeira River, and Tapajós River (FishBase 2020). The fish is a demersal species that inhabit in the fast-flowing and clean waters (Reis and Lima 2009). They reproduce at night, mostly in hiding spots and shaded areas. The male prepares the nest, which is called "pseudo-nest", and then the females lay the eggs in the cleaned area (Brysiewicz et al. 2011). The spawning of this fish is difficult to observe. The frequency of spawning events is low in culture conditions (Willis 2020), which reduces the observation chance.

There are very limited studies about the reproduction and larval development of Loricariids (Schmidt 2001; Secutti and Trajano 2009; da Rocha
Perini et al. 2010; Brysiewicz et al. 2011; Jumawan et al. 2014) and these information gaps should be filled. Therefore, this study aimed to evaluate the basic development stages from egg to larvae of bushymouth catfish at an hourly basis and to present some reproductive performance parameters.

\section{Materials and Methods}

\section{Rearing system and fish}

The study was carried out in the Aquarium Unit, Faculty of Fisheries, İzmir Kâtip Çelebi University, İzmir, Turkey. In the experiment, three $240-\mathrm{L}$ glass aquariums $(120 \times 50 \times 40 \mathrm{~cm})$ were used. Aeration was supplied to each aquarium from a central blower with a power of $1.75 \mathrm{~kW}$. A biochemical filter (Xinyou XY 380, China) was also installed at the end of the air hose in each aquarium to control the ammonia levels and provide particle filtration. The municipal water that was left for 2 days to remove chlorine and adjust the temperature of the water was used in the aquariums. About $30 \%$ of the aquarium water was renewed twice a week with dechlorinated tap water. The photoperiod was maintained at 10:14 (light: dark). Unconsumed feeds and fecal wastes were removed from the aquariums by siphoning. Clay pseudo-nests were placed in aquariums to provide spawning ground and broodstocks were regularly followed up for 6 months.

Nine bushymouth catfish (Ancistrus dolichophterus) were obtained from an importer company (İstanbul, Turkey). The fish were stocked into the aquariums after the transportation and adapted to the conditions. At the beginning of the trial, the weight and total lengths of bushymouth catfish were measured and recorded as an average of $10.5 \pm 0.3 \mathrm{~g}$ and $9.5 \pm 0.2 \mathrm{~cm}$, respectively. Three fish were stocked to aquariums with 1:2 (male: female) ratio. Bushymouth catfish broodstocks were fed to near satiation twice daily with $1 \mathrm{~mm}$ commercial trout pellets (51\% protein, $15 \%$ lipid).

\section{Evaluation of reproduction parameters}

After each mating and spawning, females were removed from the aquariums. The eggs were checked daily in all pseudo-nests to collect reproductive performance data. Since the eggs are sticky, only unfertilized eggs were removed whereas healthy eggs were left in the nests so as not to disturb. Then, a routine daily check was made and the number of dead eggs, if any, was recorded and removed from the aquariums. The eggs, larvae, and offspring in the pseudo-nests were counted monthly (November 2017-April 2018) at each stage. According to these data, average seed production (ASP), fertilization rate (FR), and hatching rate (HR) parameters were 
calculated according to the following formulas;

$A S P=$ Average of total collected eggs from each treatment

$F R=100-[($ Number of total eggs - Number of non-fertilized eggs) / Number of total eggs $x$ 100]

$H R=$ Number of living larvae $/$ Number of total eggs $x 100$.

\section{Monitoring of developmental phases}

The pseudo-nests were observed twice daily (Jumawan et al. 2014) and the main stages from egg to offspring were divided into four categories (Geerinckx et al. 2008): egg, prominence of the head and tail, larvae with yolk sac, and offspring. Transition times between these categories were recorded hourly and photographed with Sony Cybershot DSC-W320. Eggs laid at night were not evaluated for this parameter due to the uncertainty of spawning time.

\section{Water parameters}

Temperature, dissolved oxygen (DO), salinity, $\mathrm{pH}$, total dissolved solids (TDS), and electrical conductivity (EC) were measured in situ with a multi-parameter device (WTW 3420i SET). Analysis of nutrient elements including ammonium-nitrogen (indophenol blue method), nitrite-nitrogen (diazotization method), nitratenitrogen (cadmium reduction method), phosphate phosphorus (phosphomolybdenum method) was performed using a spectrophotometer (Hach Lange DR 6000).

Table 1. Average water parameters in the experimental aquariums during the study.

\begin{tabular}{lc}
\hline Water Parameters & $\begin{array}{l}\text { Mean } \\
( \pm \text { S.E. })\end{array}$ \\
\hline Temperature $\left({ }^{\circ} \mathrm{C}\right)$ & $25.99 \pm 0.09$ \\
Dissolved oxygen $(\mathrm{mg} / \mathrm{L})$ & $7.52 \pm 0.03$ \\
$\mathrm{pH}$ & $7.50 \pm 0.07$ \\
Salinity $(\%)$ & $0.68 \pm 0.05$ \\
Conductivity $(\mathrm{mS} / \mathrm{cm})$ & $1.32 \pm 0.08$ \\
Hardness $\left({ }^{\circ} \mathrm{dH}\right)$ & $10.08 \pm 0.12$ \\
Total dissolved solids $\left(\mathrm{mg} / \mathrm{L}^{\circ}\right.$ & $1271.33 \pm 75.19$ \\
Ammonium nitrogen $\left(\mathrm{mgNH}_{4}{ }^{+}-\mathrm{N} / \mathrm{L}\right)$ & $0.05 \pm 0.01$ \\
Nitrite nitrogen $\left(\mathrm{mgNO}_{2}-\mathrm{N}^{-} / \mathrm{L}^{2}\right.$ & $0.09 \pm 0.01$ \\
Nitrate nitrogen $\left(\mathrm{mgNO}_{3}{ }^{-}-\mathrm{N}_{\mathrm{L}}\right)$ & $0.17 \pm 0.01$ \\
Phosphate phosphorus $\left(\mathrm{mgPO}_{4}{ }^{3-}-\mathrm{P} / \mathrm{L}\right)$ & $1.01 \pm 0.02$ \\
\hline
\end{tabular}

During the study, the water parameters of the experimental aquariums were recorded daily, and the mean values are presented in Table 1. Mean values were measured as $25.99 \pm 0.99{ }^{\circ} \mathrm{C}$ for temperature, $7.52 \pm 0.03 \mathrm{mg} / \mathrm{L}$ for $\mathrm{DO}, 7.50 \pm 0.07$ for $\mathrm{pH}, 0.68 \pm 0.05 \%$ or salinity, $1.32 \pm 0.08 \mathrm{mS} / \mathrm{cm}$ for conductivity, and $1271.33 \pm 75.17 \mathrm{mg} / \mathrm{L}$ for TDS.

\section{Data presentation}

Trial data were recorded monthly in the Microsoft Office Excel 2018 program and mean [=AVERAGE (dataset)] and standard error [=STDEV.S(dataset)/SQRT(n)] values were calculated. The graphics were created with the same program.

\section{Results}

The reproduction parameters of bushymouth catfish are shown in Table 2. The ASP of all months was found as $39.78 \pm 0.41$ and the total number of eggs was $238.67 \pm 1.20$. The mean number of fertilized eggs was counted as $178.67 \pm 0.88$ and the FR was calculated as $75.05 \pm 1.39 \%$. The mean number of living larvae was noted as $149.67 \pm 1.20$ and the HR was calculated as $62.94 \pm 0.70 \%$.

Table 2. Reproductive performance of bushymouth catfish during the experiment.

\begin{tabular}{lc}
\hline Reproduction Parameters & Mean Value $( \pm$ S.E.) \\
\hline Average seed production & $39.78 \pm 0.41$ \\
Mean number of laid eggs & $238.67 \pm 1.20$ \\
Mean number of fertilized eggs & $178.67 \pm 0.88$ \\
Fertilization rate $(\%)$ & $75.05 \pm 1.39$ \\
Mean number of living larvae & $149.67 \pm 1.20$ \\
Hatching rate $(\%)$ & $62.94 \pm 0.70$ \\
\hline
\end{tabular}

Monthly numbers of total seeds (laid eggs, fertilized eggs, and living larvae) are shown in Figure 1. The highest number of laid eggs was observed in January with $41.00 \pm 1.15$. A higher number of fertilized eggs and living larvae were observed in March with $31.33 \pm 0.67 \%$ and $25.33 \pm 0.33 \%$, respectively.

Larval development of bushymouth catfish at an hourly basis is given in Table 3, where the time when the egg was spawn was assumed to be the zero. The prominence of the head and tail took $55 \mathrm{~h}$, consumption of the yolk sac $85 \mathrm{~h}$, and the transition to larvae stage $105 \mathrm{~h}$. These developmental stages are displayed in Figure 2.

Table 3. Transition times of basic pre-larval and larval development phases of bushymouth catfish.

\begin{tabular}{lc}
\hline Development Phase & Time (h) \\
\hline Prominence of the head and tail & $55.17 \pm 0.85$ \\
Consuming the yolk sac & $85.22 \pm 0.78$ \\
Transition to larvae stage & $105.28 \pm 0.79$ \\
\hline
\end{tabular}




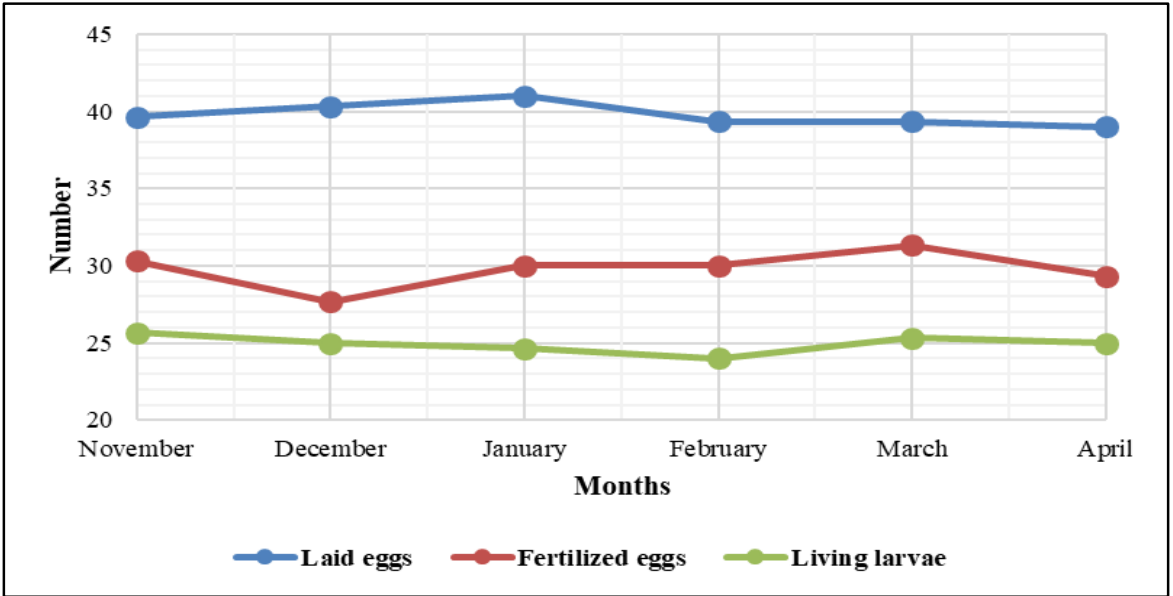

Figure 1. Monthly number of eggs laid, fertilized eggs, and living larvae of bushymouth catfish.
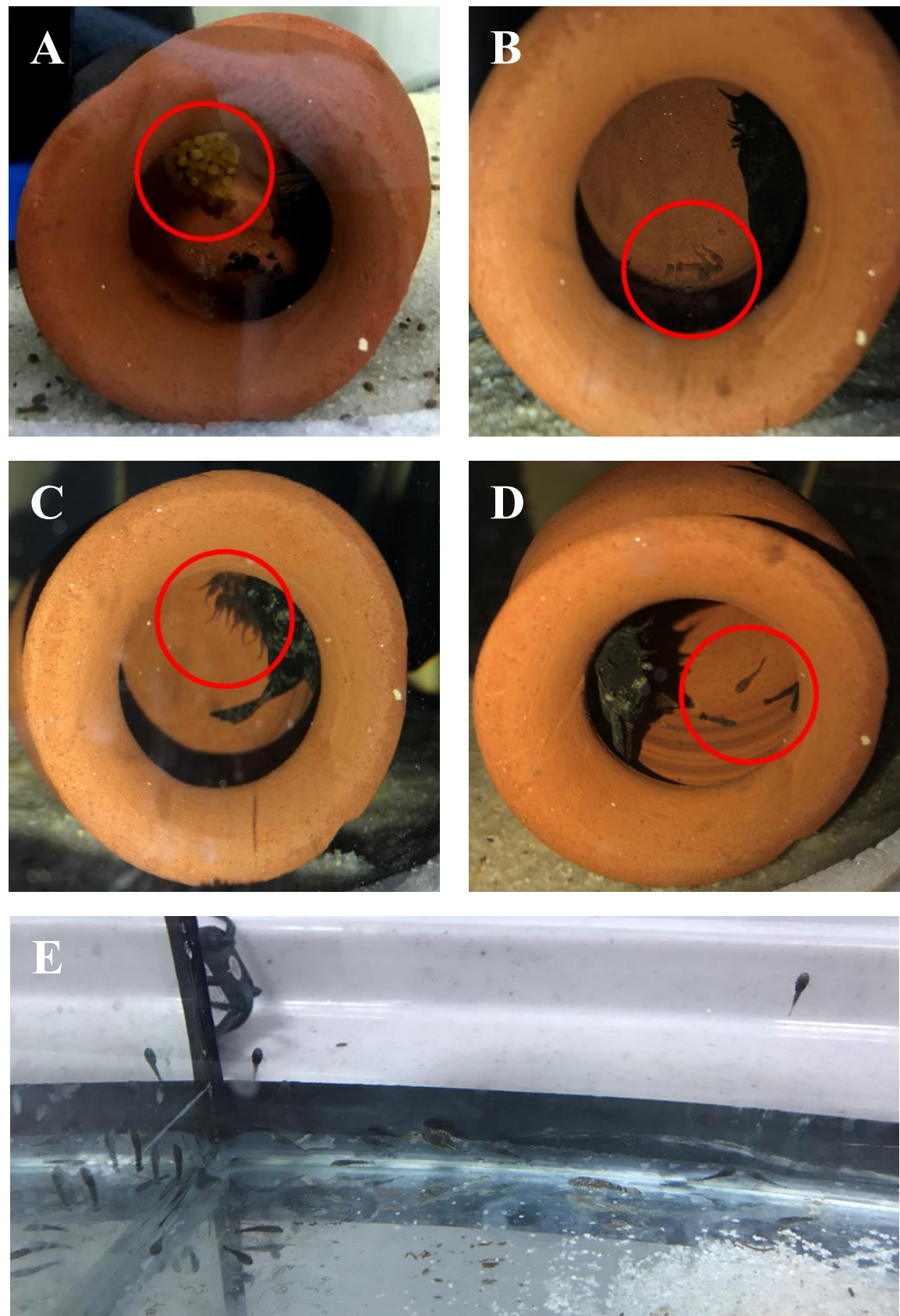

Figure 2. Development stages of bushymouth catfish. A: the eggs, B: prominence of the head and tail, C: consumption of the yolk sac, D: larvae stage, E: juveniles. 


\section{Discussion}

The results of the present study displayed that this species could reproduce easily under suitable conditions. Especially water parameters appeared to be one of the main important factors for breeding success in ornamental fish culture. For instance, in the present study, water temperature accelerated breeding events. Fish embryos and larvae are more sensitive to temperature than their adults (Wood and McDonald 1996). In a study carried with convict cichlid (Archocentrus nigrofasciatus), Vlahos et al. (2015) reported the rate of yolk sac consumption of larvae at $27{ }^{\circ} \mathrm{C}$ consumed the yolk sacs faster than those at $23{ }^{\circ} \mathrm{C}$. In the previous studies carried with Loricariids, the water temperature was held at $24^{\circ} \mathrm{C}$ for black armored catfish Rhinelepis aspera (da Rocha Perini et al. 2010), bushymouth catfish Ancistrus dolichopterus (Brysiewicz et al. 2011), and suckermouth sailfin catfish Pterygolichthys pardalis (Jumawan et al. 2014). However, Petrovický (1985) and Rymkiewicz (1988) suggested that the optimum water temperature for the embryonic development of bushymouth catfish is $25^{\circ} \mathrm{C}$. In this study, we kept the water temperature at $25.99{ }^{\circ} \mathrm{C}$ and observed an acceptable spawning and development. When considering the literature data, it can be concluded that water temperature between 24 and $26{ }^{\circ} \mathrm{C}$ seems to be optimum for the breeding of bushymouth catfish. There is a paucity of information about the optimum water parameters for broodstock bushymouth catfish. However, Brysiewicz et al. (2011) suggested $6.5 \mathrm{pH}$ as the optimum for the development of bushymouth catfish, which is lower than that of our study, 7.5. Taken together, a neutral water $\mathrm{pH}$ (6.5-7.5) would be suitable for the reproduction of bushymouth catfish.

Bushymouth catfish females laid their eggs during the six months with an average of $39.78 \pm 0.41$ with the highest number in January $(41.00 \pm 1.15)$. The previous studies pointed out that this species spawned 30-100 eggs at a time (Petrovicky 1985; Rymkiewicz 1988), which is consistent with this study. The FR and HR were found as $75.05 \%$ and $62.94 \%$ in this study, respectively. da Rocha Perini et al. (2010) collected the black-armored catfish $(R$. aspera) from the Paracatu River, Brazil and found an FR of $72.4 \%$ when they injected carp pituitary to both males and females. Also, Jumawan et al. (2014) caught the suckermouth sailfin catfish ( $P$. pardalis) from the Marikina River, Philippines and they noted that the FR and HR of fish injected with human chorionic gonadotropin (HCG) were $88.3 \%$ and $48.6 \%$, respectively. Satisfactory breeding success was recorded in the present study without a hormone injection. The main difference between those summarised above and the present study is that broodstock fish were collected from nature in the former whereas culture-based broodstock was used in the latter, which may explain a slightly better FR and HR in the present study due to the selective breeding success of broodstocks in the controlled conditions.

There are huge differences in aquarium fish species in terms of the duration of embryonic and larval developmental stages. Various distinctions have been observed even in large ornamental fish families such as Cichlidae. For instance, the larval periods of substrate-brooder American cichlids are longer than mouth-brooder African cichlids considering the literature findings. While the larval development in common cichla (Cichlasoma dimerus), discus (Symphysodon discus), angelfish (Pterophyllum scalare), and midas cichlid (Amphilophus spp.) were completed in around 24-42 days (Meijide and Guerrero 2000; Çelik 2010; Çelik et al. 2014; Kratochwil et al. 2015), the study conducted by Karadal (2016) on four mbuna cichlid species, including rusty cichlid (Iodotropheus sprengerae), kenyi (Maylandia lombardoi), auratus (Melanochromis auratus) and demasoni (Pseudotropheus demasoni), reported that the larval stages lasted 19-21 days. However, there are several studies conducted on the larval development of armored and suckermouth catfish species. Savaş and Timur (2006) and Ünal and Aral (2008) reported that peppered cory (Corydoras paleatus) consumed their yolk sacs in 1.5 and 4 days, respectively, suggesting that differences in larval development are the case even among different individuals of the same species. The main reason for this appears to be differences in the environmental conditions and physical parameters between the studies. In the study conducted by da Rocha Perini et al. (2010), the embryos of black armored catfish ( $R$. aspera) injected with by the pituitary occurred in $9 \mathrm{~h}$ and 40 min after the fertilization, and the embryogenesis was completed in $45 \mathrm{~h}$ and $50 \mathrm{~min}$ (Table 4). The same study stated that the yolk sac was completely absorbed in 120 h. Jumawan et al. (2014) reported that in suckermouth sailfin catfish ( $P$. pardalis) injected with human chorionic gonadotropin (HCG), embryonic development was completed in $168 \mathrm{~h}$ and 30 min after fertilization, and yolk sac consumption lasted 8 days after incubation. Brysiewicz et al. (2011) reported that embryonic development was completed in 4.25 days $\left(102{ }^{\circ} \mathrm{D}\right.$ at $\left.24{ }^{\circ} \mathrm{C}\right)$ in bushymouth catfish. In the present study, embryonic development lasted in 2.29 days $(55 \mathrm{~h})$ and the yolk sac was consumed in 3.54 days $(85 \mathrm{~h})$. The complete larval development lasted $105 \mathrm{~h}$ at $26^{\circ} \mathrm{C}\left(113.75^{\circ} \mathrm{D}\right)$. Although some similarities with the literature to 
a certain degree, faster larval development phases of bushymouth catfish were the case in this study most probably due to higher water temperature.

Briefly, some fundamental reproduction parameters of bushymouth catfish, one of the important ornamental fish species, were determined in this study. Further research is needed to develop an efficient production method to discover the embryonic and larval development in detail in this species.

Table 4. Comparisons of hormone application, embryonic stage and their times in previous studies and the current study.

\begin{tabular}{|c|c|c|c|c|c|}
\hline Species & Latin Name & $\begin{array}{l}\text { Hormone } \\
\text { Application }\end{array}$ & Time & Event & Author(s) \\
\hline \multirow[t]{3}{*}{$\begin{array}{l}\text { Black } \\
\text { armored catfish }\end{array}$} & Rhinelepis aspera & $\begin{array}{l}\text { Pituitary } \\
\text { injection }\end{array}$ & $9 \mathrm{~h} 40 \mathrm{~min}$ & Embryos formed & 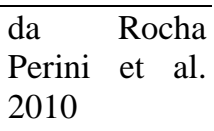 \\
\hline & & & $45 \mathrm{~h} 50 \mathrm{~min}$ & $\begin{array}{l}\text { Embryogenesis } \\
\text { completed }\end{array}$ & \\
\hline & & & $120 \mathrm{~h}$ & Yolk sac consumed & \\
\hline \multirow[t]{2}{*}{$\begin{array}{l}\text { Suckermouth } \\
\text { sailfin catfish }\end{array}$} & Pterygolichthys pardalis & $\begin{array}{l}\text { HCG } \\
\text { injection }\end{array}$ & $168 \mathrm{~h} 30 \mathrm{~min}$ & $\begin{array}{l}\text { Embryonic } \\
\text { development } \\
\text { completed }\end{array}$ & $\begin{array}{l}\text { Jumawan et } \\
\text { al. } 2014\end{array}$ \\
\hline & & & $8 \mathrm{~d}$ & Yolk sac consumed & \\
\hline $\begin{array}{l}\text { Bushymouth } \\
\text { catfish }\end{array}$ & Ancistrus dolichopterus & None & $4 \mathrm{~d} 6 \mathrm{~h}$ & $\begin{array}{l}\text { Embryonic } \\
\text { development } \\
\text { completed }\end{array}$ & $\begin{array}{l}\text { Brysiewicz et } \\
\text { al. } 2011\end{array}$ \\
\hline \multirow[t]{3}{*}{$\begin{array}{l}\text { Bushymouth } \\
\text { catfish }\end{array}$} & Ancistrus dolichopterus & None & $55 \mathrm{~h}$ & $\begin{array}{l}\text { Embryonic } \\
\text { development } \\
\text { completed }\end{array}$ & Present study \\
\hline & & & $85 \mathrm{~h}$ & Yolk sac consumed & \\
\hline & & & $105 \mathrm{~h}$ & $\begin{array}{l}\text { Larval development } \\
\text { completed }\end{array}$ & \\
\hline
\end{tabular}

\section{Acknowledgements}

The present study was carried out as a master thesis by Mustafa Deniz and prepared in Graduate School of Natural and Applied Sciences, İzmir Kâtip Çelebi University, İzmir, Turkey. Some parts of this study have been presented in the International Congress on Engineering and Life Science, Kastamonu, Turkey as a poster presentation on April 26-29th, 2018.

\section{References}

APPA 2020. American Pet Products Association; [Available on Feb 2020]. Available at: https://www.americanpetproducts.org/press_industryt rends.asp

Bassleer G. 2015. The global ornamental aquarium industry: Facts and figures - Part I. OFI J. 77:24-26.

Brysiewicz A, Szulc J, Formicki K, Tański A, KorzeleckaOrkisz A. 2011. The structure and the embryogenetic role of eggs and egg membranes of Ancistrus dolichopterus (Actinopterygii: Siluriformes: Loricariidae). Acta Ichthyol Piscat. 41(3):223-227. doi: 10.3750/AIP2011.41.3.10

Çelik İ. 2010. Characterization by microphotography of larval and prejuvenile stage of discus fish
(Symphysodon spp.). Journal of FisheriesSciences.com. 4(1):99-111. doi: 10.3153/jfscom.2010009

Çelik İ, Çelik P, Gürkan M, Şahin T. 2014. Larval development of the freshwater angelfish Pterophyllum scalare (Teleostei: Cichlidae). Turk J Fish Aquat Sci. 14:863-874. doi: 10.4194/1303-2712-v14_4_03

da Rocha Perini V, Sato Y, Rizzo E, Bazzoli N. 2010. Biology of eggs, embryos and larvae of Rhinelepis aspera (Spix \& Agassiz, 1829) (Pisces: Siluriformes). Zygote. 18(2):159-171. doi: 10.1017/S0967199409990165

Dey VK. 2016. Global trade in ornamental fish. INFOFISH Int. 4:52-55.

Evers HG, Siedel I. 2005. Catfish atlas. Osnabrück: Mergus Verlag GmbH 944 p.

FAO 2017. Food and Agriculture Organization. AQUASTAT database; [Available on: Feb 2020]. Available at: http://www.fao.org/nr/water/aquastat/ main/index.stm

FishBase 2020. Ancistrus dolichopterus Kner, 1854; [Available on: Feb 2020]. Available at: http://www.fishbase.org/summary/Ancistrusdolichop terus.html

Geerinckx T, Verhaegen Y, Adriaens D. 2008. 
Ontogenetic allometries and shape changes in the suckermouth armoured catfish Ancistrus cf. triradiatus Eigenmann (Loricariidae, Siluriformes), related to suckermouth attachment and yolk sac size. J Fish Biol. 72:803-814.

doi: 10.1111/j.1095-8649.2007.01755.x

Hill JE, Yanong RPE. 2010. Freshwater ornamental fish commonly cultured in Florida. University of Florida IFAS Extension, Circular No. 54, 5 p.

Jumawan JC, Herrera AA, Vallejo Jr B. 2014. Embryonic and larval development of the suckermouth sailfin catfish Pterygoplichthys pardalis from Marikina River, Philippines. Eur J BioSci. 8:38-50.

doi: 10.5053/ejobios.2014.8.0.4

Karadal O. 2016. Identification of larval and pre-juvenile development and effects of different feeding frequencies on reproductive performance, pigmentation, growth and survival of mbuna cichlid species (Iodotropheus sprengerae, Maylandia lombardoi, Melanochromis auratus, Pseudotropheus demasoni) [Doctorate Thesis]. Ege University. 130 p.

Kratochwil CF, Sefton MM, Meyer A. 2015. Embryonic and larval development in the Midas cichlid fish species flock (Amphilophus spp.): A new evo-devo model for the investigation of adaptive novelties and species differences. BMC Developmental Biol. 15(1):12 p. doi: 10.1186/s12861-015-0061-1

Marranzino A. 2018. Where do aquarium fish come from? Massive Science; [Available on: Feb 2020]. Available at: https://massivesci.com/articles/aquarium-fishsource

Meijide FJ, Guerrero GA. 2000. Embryonic and larval development of a substrate-brooding cichlid Cichlasoma dimerus (Heckel, 1840) under laboratory conditions. J Zool. 252(4):481-493. doi: 10.1111/j.1469-7998.2000.tb01231.x

Olivier K. 2001. The ornamental fish market. FAO/Globefish Research Programme, Vol. 67. Rome: United Nations Food and Agriculture Organisation.

Penning M, Reid GMcG, Koldewey H, Dick G, Andrews B, Arai K, Garratt P, Gendron S, Lange J, Tanner K, Tonge S, van den Sande P, Warmolts D, Gibson C. 2009. Turning the tide: A global aquarium strategy for conservation and sustainability. Bern: World Association of Zoos and Aquariums 90 p.
Petrovický I. 1985. Tropikalne ryby akwariowe (in Polish). Warsaw: PWRiL 224 p.

Reis R, Lima F. 2009. Ancistrus dolichopterus. The IUCN Red List of Threatened Species 2009: e.T167809A6385972; [Available on: Feb 2020]. Available at: http://www.iucnredlist.org/details /full/167809/0

Rymkiewicz A. 1988. Uwagi o hodowli i rozmnażaniu "glonojadów" (in Polish). Magazyn Akwarium, 2:(104). Available at: https://akwamania.mud.pl/archiwum/a104/a104,3.html.

Savaş E, Timur M. 2006. Microscopic investigation of embryologic and larval development on the street sweeper (Corydoras paleatus, Jenyns 1842). J Fac Vet Med İstanbul Univ. 32(1):47-56.

Schmidt RE. 2001. Loricaria cataphracta: parental care and description of early larvae. Ichthyol Explor Freshw. 12(3):235-240.

Secutti S, Trajano E. 2009. Reproductive behavior, development and eye regression in the cave armored catfish, Ancistrus cryptophthalmus Reis, 1987 (Siluriformes: Loricariidae), breed in laboratory. Neotrop Ichthyol. 7(3):479-490. doi: 10.1590/S1679-62252009000300016

Türkmen G, Alpbaz A. 2001. Studies on aquarium fish imported to Turkey and the results (in Turkish with English abstract). EgeJFAS, 18(3-4):483-493.

Ünal H, Aral O. 2008. Investigation of reproduction and larvae development on peppered cory (Corydoras paleatus Jenys, 1842). Journal of FisheriesSciences.com. 2(1):1-18. doi: 10.3153/jfscom.2008001

Vlahos N, Vasilopoulos M, Mente E, Hotos G, Katselis G, Vidalis K. 2015. Yolk-sac larval development of the substrate-brooding cichlid Archocentrus nigrofasciatus in relation to temperature. Integrative Zool. 10(5):497-504.

Willis, S. 2020. Farming ornamental fish; [Available on: Feb 2020]. Available at: http://aquaculturetraining.com.au/pdf/ornamentalfish-culture-practices.pdf

Wood CM, McDonald DG. 1996. Global warning: Implications for freshwater and marine fish. Cambridge: Cambridge University Press, Society for Experimental Biology Seminar Series 61, pp. 177223. 